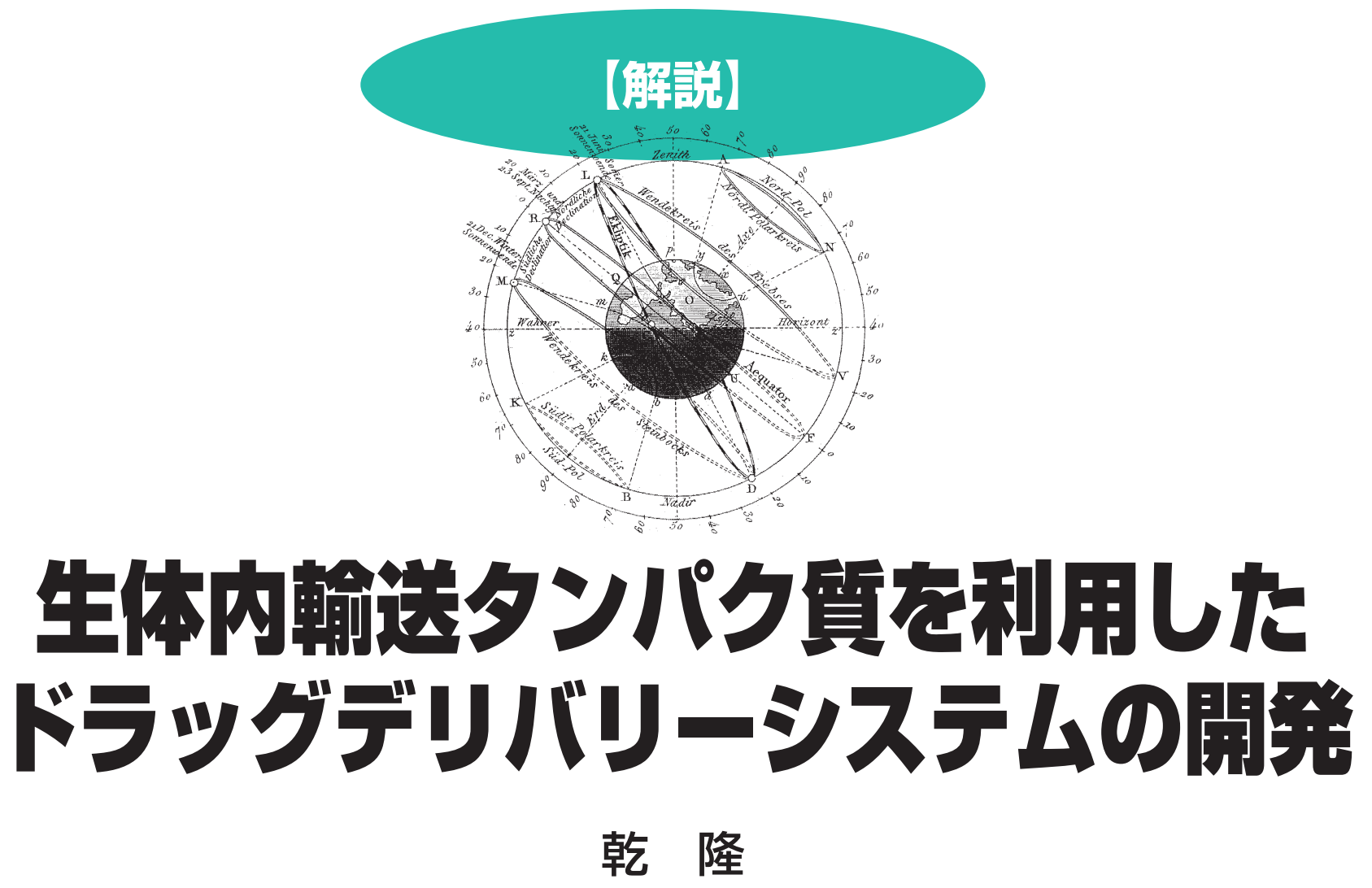

ゲノム創薬により生み出される医薬候補化合物は, 総じて分 子量が大きく, 難水溶性である. 化学修飾により水溶性を高 めることはできるが, 薬剤活性が減じられる場合が多い。こ のような難水溶性薬剤は, 前臨床段階で薬㓣開発から除外さ れる. 本課題に対して技術面で重要な鍵を握っているのが, 難水溶性薬剤を可溶化し，標的組織（細胞）まで輸送すると ともに，薬剤を効率的に機能発現させることのできるDDS (drug delivery system: 薬物送達システム) の開発である. 薬理活性の高い難水溶性薬剤を効率的に疾患部に輸送できれ ば，副作用の少ない治療が可能となり，医薬品開発・創薬分 野において新たなブレークスルーとなりうる。本稿では, DDS開発の現状を紹介するとともに, 生体内輸送タンパク 質であるL-PGDS (lipocalin-type prostaglandin D synthase, リポカリン型プロスタグランジンD合成酵素）と，本タンパ ク質を利用した難水溶性薬剤に対する新規DDS開発への試 みを紹介する。

\title{
医薬品におけるDDS
}

日本に扔いて薬価基準に収載されている医薬品は,

Development of Drug Delivery System by Using Transporter Protein

Takashi INUI, 大阪府立大学大学院生命環境科学研究科

ジェネリック医薬品（後発医薬品）を含めて約 14,900品 目である ${ }^{(1)}$ 。これら医薬品の開発は, 基礎研究, 非臨床 試験，臨床試験など多くの過程を 10 年以上の年月をか けて行う。ハイスループット・スクリーニングやコンビ ナトリアル・ケミストリーを駆使して, 多くの化合物が 薬片候補化合物としてスクリーニングされる。しかし, これらの候補化合物から実際に新薬として認可されるの は，約 3 万分の 1 という極めて低い確率であり，ほとん どの化合物は研究開発途中で脱落する. その原因とし て,「化合物が難水溶性である」,「化合物に副作用があ る」,「ADME (Absorption: 吸収, Distribution: 分布, Metabolism: 代謝, Excretion: 排泄) に問題があり, 十 分な BA (bioavailability: 生物学的利用能) が得られな い」ことが挙げられる。一方，すでに上市されている医 薬品のなかにも，抗がん剂などのように副作用をもつも のや，BAを獲得するために多量投与が必要な薬剤も存 在する。これらの問題を解決するために, 開発中止に なった薬剤候補の復活, 上市医薬品の副作用軽減, そし てBAの獲得などを目指した新規DDSの開発が世界的 に展開されている.

DDSとは，薬剤分子を異なる物質で包摂，あるいは 
薬剤を結合した複合体を目的の臓器, 組織や細胞へピン ポイントに輸送し，必要量の薬剤を必要な時間だけ作用 させることを目指す技術である，すなわち，薬効を最大 限に発揮させるために, 薬剤の体内動態を制御する技 術・システムの総称である. DDSが担うべき機能は, 薬剂の標的化，放出制御，吸収改善であり，これらす心゙ てをクリアーできる薬剤キャリアーを開発することによ り，優れたDDSを創製することができる.

\section{1. 薬剤の標的化}

薬剂の標的化とは，目的としている疾患部にのみ薬剂 を輸送することであり，輸送担体の特異な性質を利用し た受動的標的化，およびリガンドと受容体間の結合反応 作用を付加した能動的標的化がある. 受動的標的化の代 表的な例に, EPR (enhanced permeation and retention）効果がある。がん組織の新生血管は，正常組織の 血管と比べて粗悪であるため, 高分子や微粒子が流出し やすいという性質があり，これを $\mathrm{EPR}$ 効果という ${ }^{(2)}$. この性質を利用し，リポソームや高分子ミセルに薬郕を 包摂し（直径：10～100 nm），がん組織に蓄積させる 技術の開発が盛んに行われている。一方, 能動的標的化 の代表的な例として, 疾患標的ペプチドがある．標的ペ プチドは，特定の組織や疾患部位に特異的に発現してい る受容体に特異的に結合する。このペプチドを輸送体に 付加することにより, 標的部位にのみ薬剤を輸送するこ とが可能になる.

\section{2. 放出制御}

放出制御とは，血中における薬剂濃度を一定時間保 ち, 疾患部位における濃度を高めることにより薬効を発 揮させ，かつ副作用が出ない濃度に抑えることであり， この制御により薬剤の投与回数を減らすことができる. 放出制御には，高分子などによって薬剂を包摂すること により拡散を制御する徐放化, 光, 温度, 電気や磁気な ど外部からの物理的刺激により薬剤を放出させる外部刺 激応答, および各組織における酸化・還元力や $\mathrm{pH}$ 変化 などの内部刺激により薬剤を放出させる内部刺激応答が ある。

\section{3. 吸収改善}

吸収改善とは，薬剂を極性官能基で修飾したり，薬剤 担体を工夫することにより薬剤の消化管吸収を制御する ことである，たとえば，脂溶性が高く難水溶性である薬 凨を極性基により修飾し，水溶性を高めることのできる プロドラッグ化がある．プロドラッグ化された薬剤は体 内に吸収され，血清や肝臓などに存在する酵素によって 活性代謝物に変換された後, 本来の活性型薬剤となり薬 効を発揮する. 一方, 輸送担体の工夫としては，ラウリ ン酸ナトリウムなどの薬剤吸収促進作用を有する成分を 加えたり, CMC（カルボキシメチルセルロース）やシ クロデキストリンなどの薬剤可溶化成分を加えることな どがある.

次に, DDSの製剂技術について述べる．輸送担体で

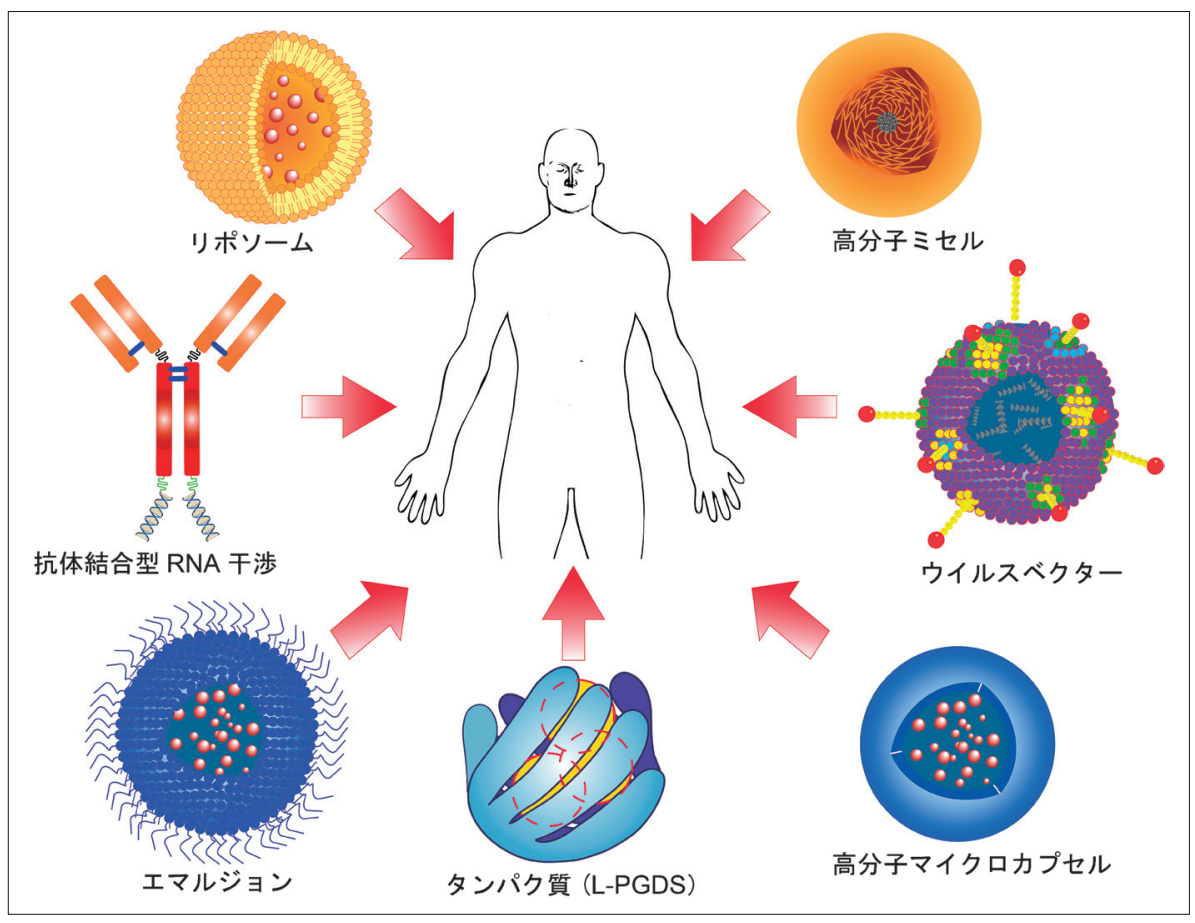

\section{図1・さまざまなDDS技術}

DDSに用いられる輸送担体として， リポソーム, 高分子ミセル, 抗体, ウイルスベクター, エマルジョン, 高分子マイクロカプセルなどが現在 開発中である。筆者らは，難水溶性 薬剂に対する輸送担体として, 生体 内輸送タンパク質であるL-PGDSを 用いたDDSの実現可能性を調查し た。 
ある製郕構成成分として，リポソーム，高分子ミセル， 抗体, ウイルスベクター, エマルジョン, 高分子マイク ロカプセルなどが用いられている（図1)。これらの成 分を上述の 3 つの技術と組み合わせることにより, DDS としての目的を達成する。現在, わが国においても, ド キシル ${ }^{\circledR}$ やアブラキサン ${ }^{\circledR}$ などの 10 種類以上の DDS製 凨がすでに承認され，実臨床に扔いて用いられている. ドキシル ${ }^{\circledR}$ は, 悪性リンパ腫, 肺がん, 消化器がん, 乳がん, 骨肉腫の治療に用いられてきたドキソルビシン 塩酸塩（アドリアシン ${ }^{\circledR}$ ) をリポソームに封入したDDS 製剤である．ドキシル ${ }^{\circledR}$ とすことにより上述のがんの みならずエイズ患者のカポジ肉腫にも適用可能となり, 薬剂単体と比較して腫瘍組織への薬剤蓄積が 10 倍程度 高まったと報告されている(3). 一方，アブラキサン ${ }^{\circledR}$ は, 卵巣がん, 非小細胞肺がん, 乳がん, 胃がん, 子宮 体がんの治療薬として用いられているパクリタキセル (タキソール ${ }^{\circledR}$ ) をヒト血清アルブミンに結合させた DDS製剤である.タキソール ${ }^{\circledR}$ は極めて難水溶性であ るため, 溶媒としてポリオキシエチレンヒマシ油や無水 エタノールを使用しなければならず，これらの溶媒に対 する過敏症の問題から, 既存製剤では過敏症対策として 同時にステロイド投与を行うことが不可欠であった。し かし，アルブミンに結合させることにより生理食塩水に 懸濁することができ，点滴での投与が可能となり，夕キ ソール ${ }^{\circledR}$ に劣らない薬効を示した ${ }^{(4)}$.しかし, 両DDS 製剤においても副作用は存在する。ドキシル ${ }^{\circledR}$ は，ア ドリアシン ${ }^{\circledR}$ 単体で示す心筋障害, 悪心・嘔吐, 脱毛 などの副作用は軽減されるが，手のひらや足の裏に紅斑 異感覚症状が見られる手足症候群, あるいは手足紅斑異 感覚症候群と呼ばれるドキシル ${ }^{\circledR}$ 特有の皮虐関連有害

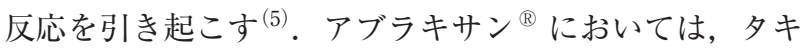
ソール ${ }^{\circledR}$ と同様の白血球減少などの骨髄抑制, しびれ などの末梢神経障害, 疲労, 脱毛, 関節痛などを引き起 こすことが報告されている( ${ }^{(6,7)}$. また，ヒト血清中のア ルブミンを使用することから血液製剂と同等の安全性確 保が要求される。 さらに, DDS製剤は薬剤単体と比較 して, 薬価が高くなることも問題の一つである. 以上よ り，DDS開発には，DDS製剤の良い面を残し，かつ副 作用のないキャリアーの開発が望まれる.

今回筆者らは, 生体内輸送タンパク質であるL-PGDS が難水溶性薬剤に対するキャリアーとして有効であるこ とをinvivo 試験により明らかにした（図1). L-PGDS を用いることにより, 薬剤活性の高い難水溶性薬片を効 率的に疾患部に輸送できれば，難水溶性薬剤の臨床応用 例を拡大し, 製薬企業で困難を極めていた薬剤溶解度に
対する問題を解決することができる.

\section{L-PGDSの多機能性}

L-PGDSは, 中枢神経系, 生殖器（精巣，前立腺，卵 巣，卵管)，抒よび心臓に局在し，ヒト脳脊䯣液中の主 要タンパク質である $\beta$-トレースと同一タンパク質であ る ${ }^{(8)}$. L-PGDSは，細胞膜成分であるアラキドン酸由来 の $\mathrm{PGH}_{2}$ を基質として, $\mathrm{PGD}_{2}$ への異性化反応を触媒す る ${ }^{(9)} . \mathrm{PGD}_{2}$ は, 睡眠誘発作用, 気管支喘息などのアレ ルギーや炎症反応など多様な生理現象にかかわることが 報告されている ${ }^{(10)}$. 化学修飾や部位特異的変異法を用 いた変異型L-PGDSの酵素化学的解析により, L-PGDS は還元型グルタチオンやジチオスレイトールなどの還元 剤存在下に拈いて, 異性化反応を触媒すること, 遊離型 システイン残基（Cys65）が触媒活性中心であることが 報告されている(11)。昨年, 筆者らのグループは, 酵素 活性中心であるCys65のチオール基（-SH）がスルフィ ニル化 $\left(-\mathrm{SO}_{2} \mathrm{H}\right)$ により, 過酸化水素 $\left(\mathrm{H}_{2} \mathrm{O}_{2}\right)$ から産生 された活性酸素 $\left(\mathrm{O}_{2}{ }^{-}\right)$を除去し, 活性酸素誘導性の神 経細胞死を有意に抑制することを発見し，L-PGDSが活 性酸素スカベンジャーとして神経組織を保護する役割を 担っている可能性を示した ${ }^{(12)}$.

一方，アミノ酸配列の相同性により，L-PGDSはリポ カリンファミリーに属することが知られている ${ }^{(13)}$.リ ポカリンファミリータンパク質は, ビタミン A 誘導体 のレチノイン酸や脂肪酸などの疎水性低分子を結合し, それらの輸送や貯蔵にかかわる輸送タンパク質群である と考えられている。 また，本ファミリータンパク質は， 昆虫類, 甲殼類, 両生類, 鳥類, 哺乳類などに存在し, レチノール結合タンパク質， $\beta$-ラクトグロブリン，アポ リポタンパク質 $\mathrm{D}$, 臭物質結合タンパク質, ビリン結合 タンパク質, 主要尿タンパク質などを含めた 100 種類以 上のメンバーがすでに報告されている(14) (図2)、筆者 らは, L-PGDSの生体内輸送タンパク質としての機能に 着目し, 蛍光消光効果法, 誘起円二色性分光法, および 等温滴定型熱測定法 (ITC) などの各種分子間相互作用 解析法を駆使し，L-PGDSの疎水性低分子に対する結合 特異性を調查した(15). その結果, ヒト由来L-PGDSは, 血中へム代謝産物であるビリベルジンやビリルビン， レ チノイン酸，および甲状腺ホルモンである L-サイロキシ ンなど, 分子量や化学構造が異なるさまざまな疎水性低 分子を高親和性（解離定数 $K_{\mathrm{d}}=3 \mathrm{nM} \sim 15 \mu \mathrm{M} ）$ に結合 し，L-PGDSがさまざまな疎水性低分子に対して「幅広 い選択性」をもつことを証明した ${ }^{(15,16)}$ 。一方，哺乳動 

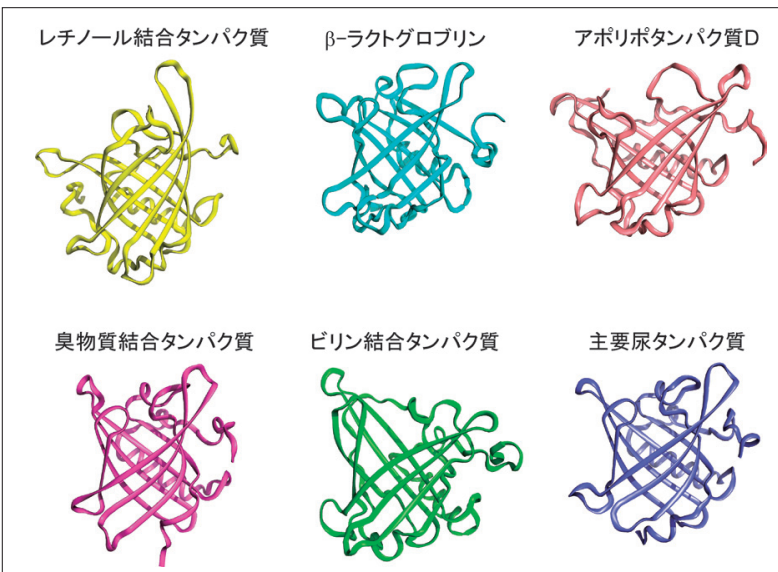

図2-X線結晶構造解析により得られたリポカリンファミリー タンパク質の構造

これらリポカリンファミリータンパク質間のアミノ酸の相同性は $20 \%$ 以下であるにもかかわらず, 三次元構造は非常に類似した $\beta$ バレル（樽型）構造を有している。

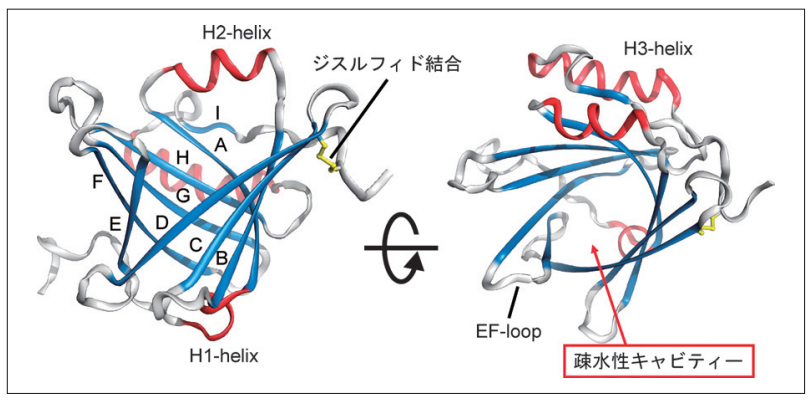

図3・NMR 測定により得られた組換え型マウス L-PGDS の溶液 構造 (Protein Data Bank ID : 2RQ0)

L-PGDSは, 9 本の逆平行 $\beta$-ストランド (A-I; 青色), 2 本の

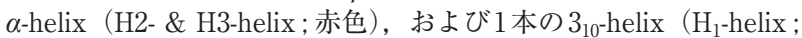
赤色）からなる $\beta$-バレル (樽型) 構造をもつ.また，Cys89 Cys186の間には, ジスルフィド結合（黄色）が形成されており， バレル内部には，疎水性キャビティをもつ.

物以外の生物種であるニワトリ，カエル，およびゼブラ フィッシュ由来L-PGDSも，疎水性低分子に対する結合 能を有する ${ }^{(17,18)}$. 以上の知見により, L-PGDSの疎水性 低分子輸送タンパク質としての機能は, 幅広い生物種間 で高度に保存されていることが判明した。また，筆者ら のグループでは, タンパク質の立体構造情報に基づい て, 疎水性低分子結合機構を探るために，NMR法を用 いたL-PGDSの構造解析を試みた。その結果, L-PGDS は， 9 本の逆平行 $\beta$-ストランドからなる $\beta$-バレル（樽 型）構造をもつ典型的なリポカリンフォールドを有し (図3), バレル構造内部の疎水性キャビティの容積は, ほかのリポカリンファミリータンパク質よりも広いこと が判明した ${ }^{(19,20)}$ 。さらに, 筆者らは, X線小角散乱法 (SPring-8, BL40B2) により, 疎水性低分子結合に伴う
L-PGDSの構造変化について調査し，L-PGDSが疎水性 低分子と複合体を形成することにより，その慣性半径が 小さくなること (Compact Packing) を見いだした. し たがって，L-PGDSの疎水性低分子に対する幅広い選択 性と高親和性は，疎水性低分子結合によりバレル上部の 構造を柔軟に変化させることによってもたらされると考 察した ${ }^{(21)}$ 。一方，タンパク質の熱安定性を評価するた めに, 示差走査型熱量計を用いてL-PGDSの熱変性過程 を調べた結果，L-PGDSの熱安定性が高いこと（ $T_{\mathrm{m}}=$ $\left.60.3^{\circ} \mathrm{C}\right)$ も判明した ${ }^{(22)}$.

以上の研究成果より, L-PGDSは, $\mathrm{PGD}_{2}$ の生合成, 活性酸素スカベンジャー，および疎水性低分子輸送など の機能を併せ持つ非常にユニークな多機能タンパク質で あることが判明した．筆者らは，これらの機能のなかで も特にL-PGDS の幅広い疎水性低分子結合能，疎水性低 分子を包み込む構造的柔軟性, おょび熱安定性に着目 し,これまで難水溶性のために研究開発から脱落した薬 剤の復活や, 現在開発中ではあるが難水溶性のためにそ の使用が困難な薬剤の可溶化において L-PGDSが利用で きるのではないかと考えた（図1). 次項では, L-PGDS が難水溶性薬剤に対する薬片輸送キャリアーとして利用 可能か否かについて行った概念検証害験, および本 DDSを実臨床に応用するための今後の課題について述 べる.

\section{L-PGDSによるDDS の構築}

L-PGDSのDDSへの応用の可能性を検証するにあた り, 薬剤作用機序がよく知られている2種類の難水溶性 薬剤，ジアゼパム (diazepam; DZP) と NBQXを用いる ことにした。 DZPは，ベンゾジアゼピン系の難水溶性 抗不安薬 $\left(\mathrm{GABA}_{\mathrm{A}}\right.$ 受容体作動薬）であり，麻酔時間の 延長効果を示すことが知られている(23). NBQXは，キ ノキサリン骨格を有し，グルタミン酸受容体の一つであ るAMPA受容体の競合的拮抗薬であり, 脳虚血時に神 経細胞保護効果を示すことが報告されているが(24)，実 臨床では, 主に水溶性を高めたNBQXナトリウム塩が 用いられている。.まず，L-PGDSに対するDZP，および NBQXの結合親和性をITCにより調べた。その結果, L-PGDSは，DZP，およびNBQXと，それぞれ $K_{\mathrm{d}}$ 值が $17 \mu \mathrm{M}$ ，および $48 \mu \mathrm{M}$ で結合することが判明した。また， ITC，および質量分析法により，1分子のL-PGDSに対 して，3分子の DZP，あるいはNBQXが結合することも 判明した（図4)。さらに，500 $\mu \mathrm{M}$ L-PGDSとDZP，扔 よびNBQXを混合することにより, 溶液中の薬剤濃度 


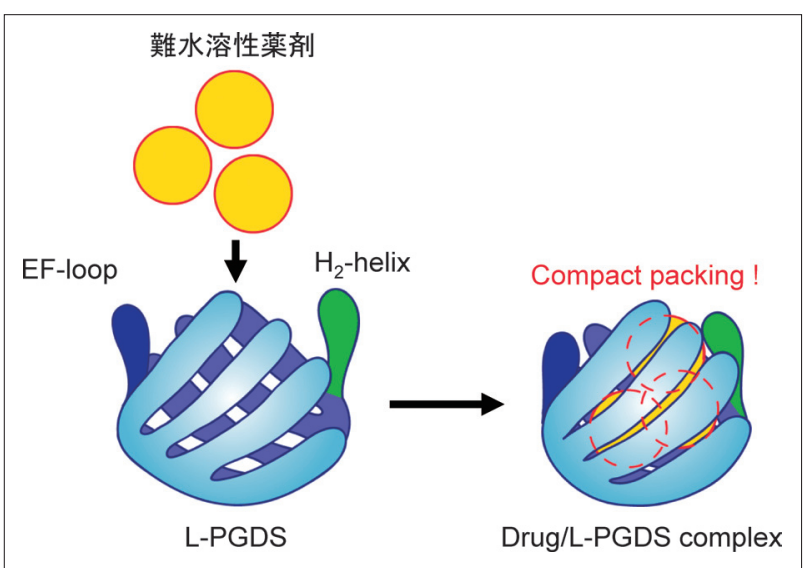

図 4 - 難水性薬剤結合に伴う L-PGDS の構造変化モデル

1分子のL-PGDSに対して3分子の難水溶性薬剂 (DZP \& NBQX) が結合する．また，L-PGDSが薬剤と複合体を形成することによ り, その慣性半径が約 $10 \%$ 小さくなる（筆者らはこの現象を compact packing と呼んでいる).

はPBS 溶液中と比較して，それぞれ 7.0 , および 2.4 倍に 上昇した。以上の結果から, L-PGDSは, 難水溶性薬剤 の強力な溶解補助剤になりうることが判明した ${ }^{(25)}$.

次に, 薬剤/L-PGDS複合体のin vivoに扔ける薬効に ついて，2種類の評価系を用いて調べたＤZPの薬効に ついては，ddy系マウスを用いた正向反射消失実験によ り確認した。ペントバルビタール麻酔下マウス（正向反 射消失）に対して，DZP/L-PGDS複合体を胃ゾンデに より経口投与し，DZPの薬効である正向反射消失時間 の延長効果が誘発されるか否かを調べた。その結果, $\mathrm{DZP} /$ カボキシメチルセルロース (DZP/CMC) 懸濁 液を投与したコントロール群に対して, 本複合体溶液投 与群では有意な正向反射消失時間の延長効果が認められ た ${ }^{(25)}$ 。さらに, DZPの活性代謝物である oxazepam と nordiazepamのマウス血中, および脳内における濃度変 化をHPLCにより定量分析したところ，DZP/L-PGDS 複合体投与群では, DZP/CMC懸濁液投与群と比較し て, 両代謝物の濃度がL-PGDSの濃度依存的に顕著に上 昇することが判明した ${ }^{(25)}$. 以上の結果から，DZPの溶 解度がL-PGDS存在下に抒いて上昇し, 経口投与後の消 化管吸収，およびBAが，DZP/CMC投与群と比較して 非常に高いことが示された。次に，スナネズミ前脳虚血 モデルを用いて, NBQX/L-PGDS複合体の静脈内投与 実験を行った。前脳虚血を施したスナネズミ静脈内に NBQX/L-PGDS 複合体を投与し, 脳内の海馬 CA1 領域 における錐体細胞に対する効果を調べた。その結果，本 複合体投与群では, PBS投与群と比較して, 有意に錐体 細胞の細胞死が抑制されることが判明した ${ }^{(25)}$ (図5).

以上の結果から，L-PGDSを用いてDZP，および

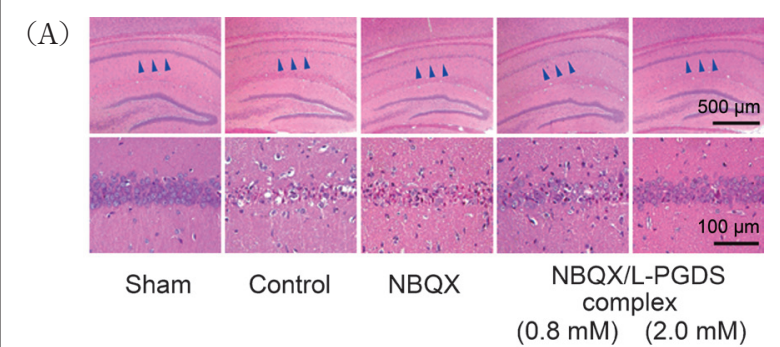

(B)

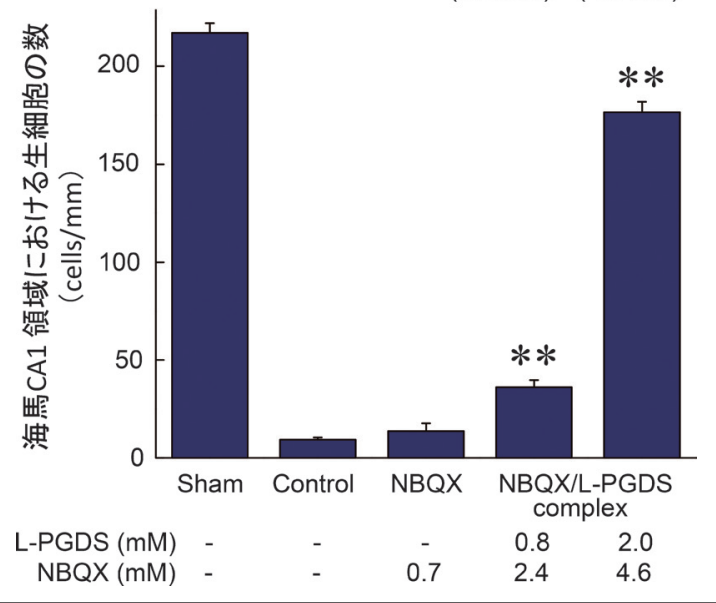

図 5 ロスナネズミ前脳虚血モデルにおける NBQX/L-PGDS 複合 体の遅発性神経細胞死抑制効果

(A) ヘマトキシリン・エオジン染色を施した海馬 CA1 領域（上図 中の矢頭部分, 下図はCA1 領域の拡大図）における錐体細胞の写 真. 前脳虚血を 5 分間施した後, 再還流直後, 10 分後, 25 分後の 3 回に分けて以下の溶液をスナネズミ静脈内に投与した。 左から sham群 (偽手術), PBS処理虚血群 (control), NBQX処理虚血 群, NBQX/L-PGDS (0.8 mM) 複合体処理虚血群, NBQX/LPGDS (2 mM) 複合体処理虚血群.（B）それぞれのグループの海 馬 CA1 領域における生細胞数の定量的解析 $(n=5)$. デー夕は, mean $\pm \mathrm{SE}$ で表す. ** $p<0.01 v s$. control

NBQXを可溶化することにより，経口投与，および静 脈内投与の両投与法において, より効果的に難水溶性薬 剤の薬効を引き出すことができることを証明した。これ は, 生体内輸送夕ンパク質を難水溶性薬剤キャリアーと して用いた世界で初めての例である（図6）.

\section{今後の展望}

前述のように筆者らは, L-PGDSが難水溶性薬剤であ るDZPやNBQXを可溶化し，これら複合体を疾患モデ ル動物に対して経口，および静脈内投与することによ り，各薬剤の薬効を改善することから，両投与法におい てL-PGDSが薬剤キャリアーとして有用であることを示 した。冒頭にも紹介したが, DDS開発の醍醐味は, 薬 剤の「標的化」,「放出制御」，㧍よび「吸収改善」にお いて有効なキャリアーの開発，すなわちがん（悪性腫 瘍）を標的にしたDDSの開発である。がん疾患は 1981 


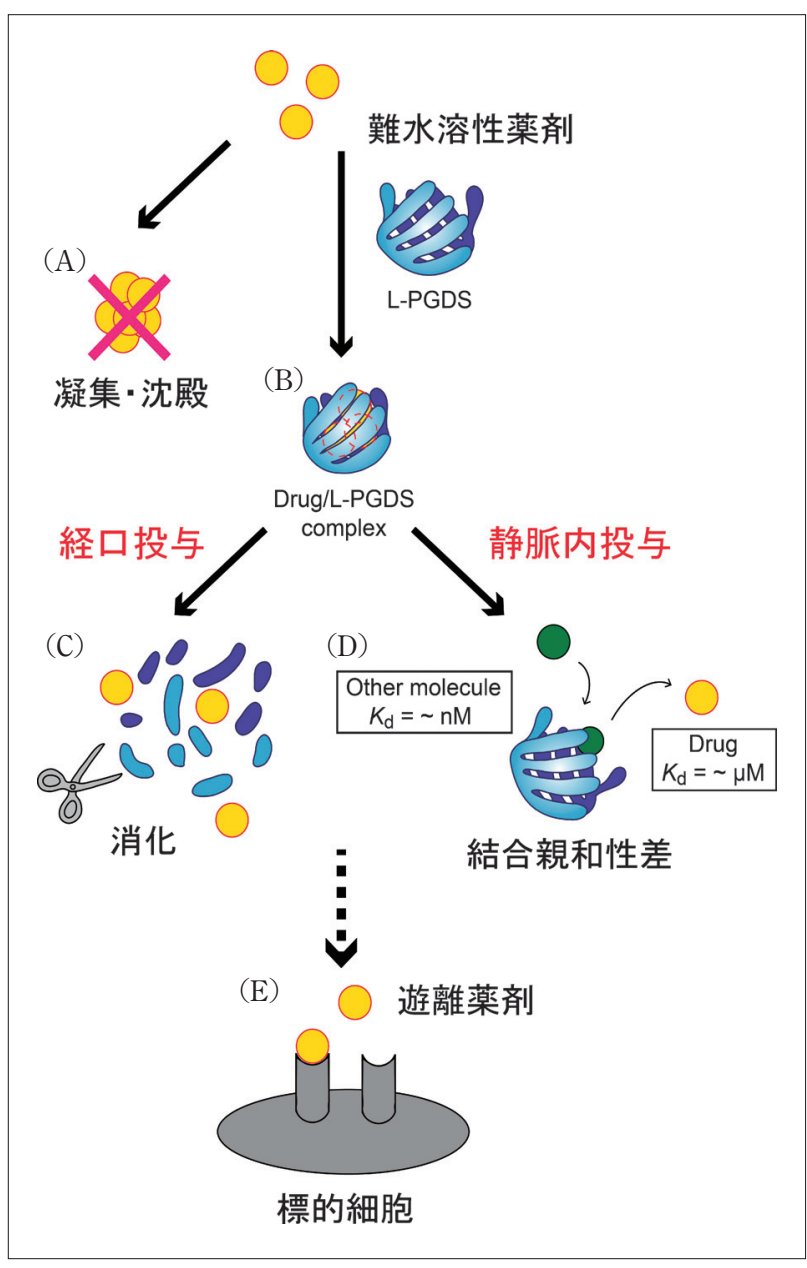

図 6 - L-PGDSによる難水溶性薬剤に対するDDSの概念.

（A）難水溶性薬剤は，水溶液中では不溶性のため, 凝集, 沈殿 し，投与が困難である。（B）L-PGDSは，難水溶性薬剤と結合す ることができ，その分子を可溶化する．（C）薬剤/L-PGDS複合体 を経口投与すると，薬剤を包摂していたL-PGDSは，消化管内に おいてプロテアーゼなどにより消化され，内包されていた薬剤が 放出されるとともに消化管から吸収される。(D) 一方, 薬郕/LPGDS 複合体を静脈内投与すると, 薬剤はへム代謝産物などのLPGDSに対する結合親和性の高い疎水性低分子と置換して血中に 放出され, 血中での薬剤濃度が高まる。（E）その後，薬剤は血流 に乗って標的細胞受容体まで迻り着き，薬効を発揮する.

年からわが国における死因の第一位を占め，2010年に は約 35 万人，年間総死亡者数の約 3 割を占めている ${ }^{(26)}$. また，がんは高齢になるにつれて，その発症リスクが高 まり，わが国の高齢化社会への移行を踏まえると，患者 数，および死亡者数は増加していくと予想される. 現 在，がんに対する治療法としては，外科的手術，放射線 治療，および抗がん剤治療の三大治療法が存在するが, 外科的手術，および放射線治療のいずれの治療を行うに しても，抗がん風との組み合わせは必須である。しか し，抗がん剤はがん細胞だけでなく正常細胞に対しても 損傷を与え，結果的には白血球数の減少，吐き気，倦意
感，食欲不振，脱毛，手足のしびれ，痛み，潰瘍，臟器 の機能低下などの副作用を伴う。これらの副作用は，患 者のQOL（quality of life, 生活の質）を著しく損ねるだ けでなく，治療を行う医師や看護士などの医療業務従事 者にとっても大きな負担となっており，特にがん疾患分 野に打けるDDS開発のニーズが高まっている。一方, 抗がん剂の多くは，難水溶性であり臨床では十分な薬効 が得られない，難水溶性ではあるが，高い薬効を有する 抗がん剂を活用できれば，これまで難水溶性がゆえに開 発中止になった薬剤を復活させることができ，難水溶性 抗がん剂の臨床応用例を拡大できる，また，製薬企業で 困難を極めていた薬剂溶解度の問題を解決し, 新規医薬 候補化合物の開発期間を大幅に短縮できる。そこで筆者 らは，次のステップとして，「難水溶性抗がん剤の可溶 化」「がん組織に対する標的指向性」，および「がん細 胞内での薬剂放出機能」を併せ持つタンパク質ナノカプ セルを作製し，副作用の少ないがん指向性DDSの開発 を目指した。

SN-38（7-ethyl-10-hydroxycamptothecin）は，植物ア ルカロイドであるカンプトテシンから合成され，DNA 複製に関与するトポイソメラーゼIを阻害する抗がん剂 である。しかし，SN-38は超難水溶性のためそのままで の投与は困難であり，その誘導体であるイリノテカン （CPT-11）が実臨床に展開され，大腸がん，肺がん，卵 巣がんなどの治療に用いられている。CPT-11は，体内 で CE (carboxyl esterase) によりSN-38に変換され抗 腫瘍効果を発揮するが (変換効率は $10 \%$ 以下)，その効 果がSN-38に比べて非常に低いこと，CE活性に個人差 があること，そして重篤な下痢を引き起こすことが報告 されている。したがって，より効率的で有効な抗腫瘍効 果を得るためには，SN-38の直接利用が望ましい，これ までに, SN-38を高分子ミセル ${ }^{(27)}$ やリポソーム ${ }^{(28)}$ へ封 入，あるいは抗体 ${ }^{(29,30)}$ に結合させたDDSの開発が行わ れており，特に高分子ミセルを用いたDDS製剤は，日 本とアメリカにおいて Phase II の臨床試験が行われてい る。しかしながら，DDSの開発には常に，輸送体の大 量調製，薬物選択性，および輸送体自身の毒性などの問 題，あるいはPEG 修飾リポソームや高分子ミセルの頻 回投与に扔ける $\mathrm{ABC}$ (accelerated blood clearance) 現 象などの課題が山積されており，わが国におけるDDS 医薬品の承認数は極めて少ない。一方, 筆者らは現在, L-PGDSをキャリアーとしたSN-38のDDS製剤化を目指 した研究を行っている。これまでの実験から，L-PGDS はSN-38を高親和性に結合すること，SN-38の溶液中濃 度が, 2 mM L-PGDS存在下に抢いてPBS存在下と比較 
して，約 300 倍も高いことを明らかにしている。また， SN-38/L-PGDS 複合体を担がんヌードマウスの静脈内に 投与したところ，本複合体投与群はCPT-11投与群に比 べて有意な抗腫瘍効果を示すことを確認している．今 後，L-PGDSにがん指向性，およびがん細胞透過性を有 するモチーフを付加することにより，副作用の少ないが んターゲットDDS の開発を実現したい。

謝辞 : 本研究の遂行に当たり, 多大なる協力をしていただいた大阪府立 大学大学院生命環境科学研究科・生体高分子機能学研究室（旧蛋白質科 学研究室）の皆さんに感謝いたします. 特に, 本解説作成に当たり, 図 の作成や原稿推敲をお願いした福原彩乃博士，久米慧嗣博士，河野正樹 氏, 山口桂右氏, 中辻匡俊氏に心より感謝いたします.

\section{文献}

1）日本製薬工業協会：“てきすとぶっく製薬産業 2012”，医 薬出版センター, 2012, p. 3.

2) J. Fang, H. Nakamura \& H. Maeda:Adv. Drug Deliv. Rev., 63, 136 (2011).

3) A. Gabizon, R. Catane, B. Uziely, B. Kaufman, T. Safra, R. Cohen, F. Martin, A. Huang \& Y. Barenholz: Cancer Res., 54, 987 (1994).

4) W. J. Gradishar, S. Tjulandin, N. Davidson, H. Shaw, N. Desai, P. Bhar, M. Hawkins \& J. O'Shaughnessy :J. Clin. Oncol., 23, 7794 (2005)

5) K. M. Skubitz: Invest. New Drugs, 20, 101 (2002).

6) L. S. Schwartzberg, F. P. Arena, D. M. Mintzer, A. L. Epperson \& M. S. Walker:Clin. Breast Cancer, 12, 87 (2012).

7) N. A. Rizvi, G. J. Riely, C. G. Azzoli, V. A. Miller, K. K. $\mathrm{Ng}$, J. Fiore, G. Chia, M. Brower, R. Heelan, M. J. Hawkins et al. :J. Clin. Oncol., 26, 639 (2008).

8) A. Hoffmann, H. S. Conradt, G. Gross, M. Nimtz, F. Lottspeich \& U. Wurster : J. Neurochem., 61, 451 (1993).

9) Y. Urade, N. Fujimoto \& O. Hayaishi:J. Biol. Chem., 260, 12410 (1985)

10) Y. Urade \& O. Hayaishi: Biochim. Biophys. Acta, 1482 , 259 (2000).

11) Y. Urade, T. Tanaka, N. Eguchi, M. Kikuchi, H. Kimura, H. Toh \& O. Hayaishi : J. Biol. Chem., 270, 1422 (1995).

12) A. Fukuhara, M. Yamada, K. Fujimori, Y. Miyamoto, T. Kusumoto, H. Nakajima \& T. Inui : Biochem. J., 443, 75 (2012).

13) H. Toh, H. Kubodera, N. Nakajima, T. Sekiya, N. Eguchi, T. Tanaka, Y. Urade \& O. Hayaishi : Protein Engineering, 9, 1067 (1996).

14) D. R. Flower, A. C. North \& C. E. Sansom : Biochim. Biophys. Acta, 1482, 9 (2000).

15) S. Kume, Y. H. Lee, Y. Miyamoto, H. Fukada, Y. Goto \& T. Inui : Biochem. J., 446, 279 (2012).

16) T. Inui, T. Ohkubo, M. Emi, D. Irikura, Y. Urade \& O. Hayaishi :J. Biol. Chem., 278, 2845 (2003).

17) K. Fujimori, T. Inui, N. Uodome, K. Kadoyama, K. Ari- take \& Y. Urade : Gene, 375, 14 (2006)

18) D. Irikura, T. Inui, C. T. Beuckmann, K. Aritake, G. Schreiber, M. Miyano, T. Inoue \& Y. Urade :J. Biochem., 141, 173 (2007).

19) S. Shimamoto, T. Yoshida, T. Inui, K. Gohda, Y. Kobayashi, K. Fujimori, T. Tsurumura, K. Aritake, Y. Urade \& T. Ohkubo:J. Biol. Chem., 282, 31373 (2007).

20) Y. Miyamoto, S. Nishimura, K. Inoue, S. Shimamoto, T. Yoshida, A. Fukuhara, M. Yamada, Y. Urade, N. Yagi, T. Ohkubo \& T. Inui : J. Struct. Biol., 169, 209 (2010).

21） K. Inoue, N. Yagi, Y. Urade \& T. Inui :J. Biochem., 145, 169 (2009).

22) T. Iida, S. Nishimura, M. Mochizuki, S. Uchiyama, T. Ohkubo, Y. Urade, A. Tanaka \& T. Inui : FEBS J., 275, 233 (2008).

23) X. Liu, T. L. Lee \& P. T. Wong:Anesth. Analg., 102, 135 (2006).

24) M. J. Sheardown, P. D. Suzdak \& L. Nordholm : Eur. J. Pharmacol., 236, 347 (1993).

25) A. Fukuhara, H. Nakajima, Y. Miyamoto, K. Inoue, S. Kume, Y. H. Lee, M. Noda, S. Uchiyama, S. Shimamoto, S. Nishimura, T. Ohkubo, Y. Goto, T. Takeuchi \& T. Inui :J. Control. Release, 159, 143 (2012).

26）財団法人がん研究振興団：“がんの統計 '11 CANCER STATISTICS IN JAPAN-2011”, 2011, p. 24.

27) T. Hamaguchi, T. Doi, T. Eguchi-Nakajima, K. Kato, Y. Yamada, Y. Shimada, N. Fuse, A. Ohtsu, S. Matsumoto, M. Takanashi et al. : Clin. Cancer Res., 16, 5058 (2010).

28) R. Kurzrock, S. Goel, J. Wheler, D. Hong, S. Fu, K. Rezai, S. K. Morgan-Linnell, S. Urien, S. Mani, I. Chaudhary et al. : Cancer, 118, 6144 (2012).

29) R. M. Sharkey, S. V. Govindan, T. M. Cardillo \& D. M. Goldenberg: Mol. Cancer Ther., 11, 224 (2012).

30) T. M. Cardillo, S. V. Govindan, R. M. Sharkey, P. Trisal \& D. M. Goldenberg: Clin. Cancer Res., 17, 3157 (2011).
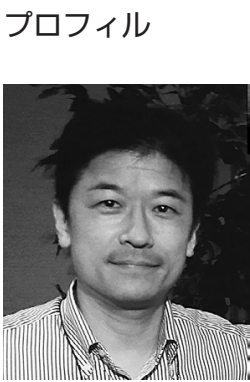

\section{乾 隆 (Takashi INUI)}

<略歴>1987年関西学院大学理学部物 理学科卒業 / 1989 年関西学院大学大学院 理学研究科博士前期課程修了/同年(株) 日本チバガイギー国際科学研究所研究 員 / 1997年理学博士 (関西学院大学) / 同年(株)ノバルティスファーマ宝塚研究 所研究員 / 1998年大阪バイオサイエン 不研究所分子行動生物学部門研究員/ 2002 年三重短期大学生活科学科食物栄 養学専攻助教授 / 2005 年大阪府立大学 大学院生命環境科学研究科助教授 $/ 2011$ 年同教授, 現在に至る<研究テーマと抱 負 $>$ がんターゲットDDSの開発, アフ リカ睡眠病治療薬の開発などく趣味 $>$ ウォーキング, 模型部の活動 